\title{
Shifting Currents: Science Technology Society and Environment in Northern Ontario Schools
}

\author{
Astrid Steele \\ Nipissing University
}

\begin{abstract}
The focus is on the practices of secondary science teachers in rural, resource-extraction-based communities in the boreal region of northern Ontario, Canada. In 2008 the Ontario Ministry of Education mandated that science teaching and learning should bring to the forefront consideration of the impacts of science on society and environment, and include environmental education; topics that are particularly pertinent given the location(s) of the study in logging and mining towns. Three years after the introduction of that curriculum the researcher investigates the extent to which the mandated changes have entered teacher practice. The study consists of a survey, $(n=26)$, interviews $(n=7)$ and a closer exploration of the collaboration between two teachers who work towards including social and environmental issues in their lessons. Findings provide evidence that secondary science teachers are shifting toward a stronger emphasis issues of society and environment in their practice, however teachers identified a number of concerns including an information gap, developing new lessons, program planning, assessment, and teaching in the North. A theoretical framework developed by Pedretti and Nazir was used in the analysis of the teacher collaboration. Recommendations are for professional development to specifically address the concerns raised by the teachers; as well, changes are suggested to the theoretical framework to include a stronger emphasis on environmental education.
\end{abstract}

Keywords: environmental education, rural science education, secondary science, STSE, teacher collaboration

Astrid Steele is an Assistant Professor in Education (Science Methods) at Nipissing University. Her research interests focus on the intersection of science and environmental education, especially in secondary education. In her work with teachers she endeavours to empower them to develop rich and meaningful praxes.

E-mail: astrids@nipissingu.ca

Brock Education Volume 23, No. 1, Fall 2013, pp. 18-42 


\section{Introduction}

As I drive north the boreal forest slips by, an endless ocean of black spruce, wetlands bordering on muskeg, and groves of trembling aspen. The boreal region covers $58 \%$ of northern Canada, it is economically worth $\$ 4$ billion a year, and it is home to about $14 \%$ of Canadians (Canadian Boreal Initiative). I have lived and worked in towns in Canada's boreal region for several decades and it has left its mark. This landscape elicits environmental sensibilities borne of the harshness of its topography and its seasons, and the result of a northern economy that is predicated on the brutally invasive extraction of timber and minerals. The sense of surviving and thriving in a harsh frontier lingers, and is manifest, in recreational activities that include hunting, trapping, fishing, four-wheeling, and snowmobiling. It seems that for many residents the illusion persists that the boreal is endless, and endlessly capable of absorbing human impacts. Living within close range of nature does not guarantee an environmental ethic of conservation and care. Indeed, living so close to the trees can engender a sort of myopia toward the forest; the big picture of environmental degradation goes unattended.

I believe that environmental education (EE) is a critical factor in ensuring the sustainable use of the boreal region by its inhabitants, and I further believe that formal schooling continues to be one of the powerful platforms for such learning. This research follows, and is informed by, previous action research (Steele, 2011) wherein secondary science teachers in the northern boreal region of Ontario embedded EE in their science lessons, through expectations that are formally titled Science, Technology, Society and Environment (STSE). This study is set apart from other investigations into the nature and implementation of EE/STSE in science curricula by virtue of its location; it gives voice to educators living and working in settings very different from their southern, urban counterparts. While we may have a mutual understanding of the term 'urban' as including high-density city living, the term 'rural' is not so easily defined. In its simplest terms a rural population is defined as those who live outside commuting distance of a center with more than 10,000 inhabitants (Statistics Canada). However, human interactions are usually more complex than simple numbers; rural populations are also identified through social representations that link people through shared language, symbols, and sensibilities (Halfacree, 1993). For the purpose of this investigation, the term rural will be understood to refer to the people who live and work in Ontario's boreal north, and who share certain environmental and other subcultural sensibilities.

Understanding EE in the north, particularly as secondary science teachers enact it in formal classrooms, led me to ask the questions: How do secondary science teachers in northern Ontario understand and teach to the STSE expectations? What do the reported lessons in STSE actually look like? and How do teachers understand and implement EE through STSE?

Certainly, there has been considerable research that explores how teachers include environmental education in their practice (Hart, 2003), and how science teachers accommodate STSE expectations (Pedretti \& Nazir, 2011). However, there is a gap in the literature pertaining to EE and STSE in secondary science (Steele, 2011) particularly in rural areas, corroborated by Karrow, Fazio, and Dusto (2012). Two studies in particular point to the need for additional research in rural areas: in a cross-Ontario survey for teachers about STSE and EE practices by Tan and Pedretti (2010), only $18.5 \%$ of their respondents identified themselves as rural, and in another Ontario survey by Fazio and Karrow (2011) addressing EE practices, less than 10\% of the respondents were from rural populations. Clearly, the voices and perspectives of educators in rural areas are underrepresented in STSE/EE research. 
Taking STSE and EE theoretical frameworks as underpinnings, this article examines the practices of secondary science teachers in rural northern Ontario from three vantage points: a multi-participant survey, several interviews, and actual classroom activities of two collaborating teachers.

\section{STSE and Environmental Education Theoretical Frameworks}

In Ontario, Canada, the document Acting Today, Shaping Tomorrow (Ontario Curriculum Council, 2009), informed by Shaping Our Schools, Shaping Our Future, (Ontario Ministry of Education, 2007), and supported by the Pan-Canadian Framework of Science Learning Outcomes (CMEC, 1997) directed that EE be incorporated in all school topics and in all grades. In the science curricula, for both the elementary and secondary panels, this was achieved by placing curriculum expectations that contextually examine the impacts of science and technology on issues of society and environment (STSE) at the forefront of all topics in the science curriculum. This represents a significant and profound change to Ontario science curricula, to bring into balance required content knowledge and skills with the scientific literacy of students, to make informed and wise decisions as citizens (Hodson, 2003, 2010; Ontario Ministry of Education, 2008a, 2008b; Pedretti \& Little, 2008).

The intentions of the STSE expectations are diverse: to increase student interest; to practice critical thinking and decision-making in the context of social responsibility (Pedretti, 2003); to search for data driven knowledge and act on it (Hodson, 2010); and to introduce elements of morality (Fowler, Zeidler, \& Sadler, 2009; Lee et al., 2012; Zeidler, Sadler, Simmons, \& Howes, 2004). As Pedretti, (2003) points out:

It would be a mistake to assume that STSE is a single, coherent, well articulated approach to science education, nor should it be. If the spirit of STSE education is to explore the relationships among science, technology, society and environment, then we cannot hope to capture this complexity in a neat unencumbered package. (p. 221)

\section{The Pedretti and Nazir STSE model}

More recently the multiple interpretations of STSE have been refined by Pedretti and Nazir (2011) into a coherent and comprehensive framework that allows for the analysis and discussion of different versions of STSE, as they are practiced by educators. Based on an exhaustive review of literature, and particularly Sauvé's (2005) description of currents in EE, Pedretti and Nazir describe iterations of STSE and propose that these at times overlap or run together in six STSE currents. The currents are identified using four criteria: the focus of the current, the aims of science education, the dominant approaches providing educational emphasis, and examples of strategies that speak to pedagogy and practice of the current. The six currents within STSE identified by Pedretti and Nazir (2011) are summarized below.

The Application/Design current. The focus of the Application/Design current is on problem solving based on the creative design or modification of technologies. Its educational aims are utilitarian and practical in nature and require the transmission of disciplinary knowledge and technical skills. The dominant approaches are cognitive, experiential, pragmatic, and creative. This current is most often associated with designing and building artifacts. 
The Historical current. The Historical current focuses on the connection between the human enterprises called science, and its historical, social, and cultural dimensions. Its educational aims include valuing the achievements of science and scientists. The dominant approaches are cognitive, reflexive, and affective, and it is most often associated with activities such as case studies and forms of drama.

The Logical Reasoning current. The focus of the Logical Reasoning current is to develop the ability to make decisions regarding socioscientific issues through examination of empirical evidence. The education aims are to develop citizenship, civic responsibility, decision-making, and the transaction of ideas. The Logical Reasoning current is enacted through consideration of socioscientific issues using risk/benefit and stakeholder analyses, and various argumentation and decision-making activities.

The Value Centered current. The Value Centered current focuses on the understanding of socioscientific issues through ethical and moral reasoning. Like the Logical Reasoning current, its aims are to develop citizenship and civic responsibility, however its dominant approaches are affective, moral, logical, and critical. Value Centered current strategies include considering case studies and socioscientific issues through an ethical lens.

The Socio-Cultural current. The focus of the Socio-Cultural current is the understanding that society and culture provide the context for science and technology, therefore, the educational aims of this current focus on cultural and intellectual achievements. The dominant approaches are holistic, reflexive, experiential, and affective. As well as case studies and socio-scientific issues, strategies within this current acknowledge alternate knowledge systems and the integration of curricula.

The Socio-Ecojustice current. The Socio-Ecojustice current focuses on critiquing problems of a social and/or environmental nature and then solving them by taking action. Along with civic responsibility and citizenship, this current's aims are transformative and emancipatory; its dominant approaches include creative, critical, experiential, and place-based. Strategies used in the Socio-Ecojustice current include community projects and actions plans within both local and global contexts.

\section{Environmental Education within STSE}

In the Ontario Science curriculum EE is defined as follows:

Environmental education is education about the environment, for the environment, and in the environment that promotes an understanding of, rich and active experience in, and an appreciation for the dynamic interactions of:

- The Earth's physical and biological systems

- The dependency of our social and economic systems on these natural systems

- The scientific and human dimensions of environmental issues

- The positive and negative consequences, both intended and unintended, of the interactions between human-created and natural systems.

(Ontario Curriculum Council, 2007, p. 6) 
Environmental education in Ontario science curriculum is tasked with teaching about the environment through avenues such as environmental science; in the environment, requiring that students have out-of-classroom and place-based experiences (Greenwood, 2009; Louv, 2005; Smith, 2007) through which they develop affiliation for nature (Tan \& Pedretti, 2010); and for the environment, by learning to make wise consumer and citizenship choices (Hodson, 2003, 2010), engaging in actions of stewardship (Tan \& Pedretti, 2010), and socio-political actions on behalf of environment (Hodson, 2003, 2010). This comprehensive definition of EE is consistent with the call for a broader focus for EE (Gough, 2002; Hart, 2002) beyond traditional forms such as nature and conservation studies or environmental science. Environmental education should include considerations of the impacts of science on society and environment (Hart, 2002; Hodson, 2003;). Thus, environmental education finds its strongest expression within the STSE expectations:

(STSE) within this (science) curriculum document provides numerous opportunities for teachers to integrate environmental education effectively into the curriculum. The STSE expectations provide meaningful contexts for applying what has been learned about the environment, for thinking critically about issues related to the environment, and for considering personal action that can be taken to protect the environment. (Ontario Ministry of Education, 2008a, p. 36)

As such, EE is consistent with, and may actually be embedded within, a number of the STSE currents described by Pedretti and Nazir (2011), however, it is not identified in their framework as a separate current. The STSE expectations in the Ontario science curriculum appear to provide multiple opportunities, within a broad range of topic areas, to embed EE concepts and pedagogies in secondary science curriculum. This is best illustrated by a number of STSE expectation examples taken from different grade levels and courses (Table 1); they provide a selection of possible contextual issues and questions associated with each unit of study.

Given a science curriculum that is arguably poised as a platform for a robust form of EE within STSE, and that allows for a variety of pedagogies and perspectives, the question becomes one of enactment. What pressures come to bear on teaching EE, through the STSE expectations, in a secondary science classroom, particularly one in rural northern Ontario? 
Table 1. Sample STSE expectations for Ontario Secondary Science curricula (Ontario Ministry of Education, 2008a, 2008b)

\begin{tabular}{|c|c|c|}
\hline Grade and Topic & STSE Expectation & Sample Issues/Questions Provided in the Curriculum \\
\hline $\begin{array}{l}\text { Grade } 9 \\
\text { Chemistry }\end{array}$ & $\begin{array}{l}\text { Assess social, } \\
\text { environmental, and } \\
\text { economic impacts of the } \\
\text { use of common elements } \\
\text { or compounds. }\end{array}$ & $\begin{array}{l}\text { Sample questions: How has the presence of mercury } \\
\text { in water bodies in Northern Ontario affected the } \\
\text { environment and the lives of Aboriginal people? } \\
\text { How does the widespread use of agricultural } \\
\text { chemicals in Canada or elsewhere affect the } \\
\text { economy, society, and the environment? What are } \\
\text { the economic benefits and environmental costs of } \\
\text { diamond mining for Northern Canadian } \\
\text { communities? (OME, 2008a, p. 52) }\end{array}$ \\
\hline $\begin{array}{l}\text { Grade } 11 \\
\text { Physics: } \\
\text { Kinematics }\end{array}$ & $\begin{array}{l}\text { Assess the impact on } \\
\text { society and the } \\
\text { environment of a } \\
\text { technology that applies } \\
\text { concepts related to } \\
\text { kinematics (e.g., photo } \\
\text { radar helps prevent } \\
\text { vehicular accidents and } \\
\text { reduces fuel consumption } \\
\text { associated with excessive } \\
\text { speeding). }\end{array}$ & $\begin{array}{l}\text { Sample issue: The use of the global positioning } \\
\text { system (GPS) increases accuracy in mapping, } \\
\text { surveying, navigation, monitoring earthquakes, and } \\
\text { tracking the movement of oil spills and forest fires, } \\
\text { among other benefits. However, its extensive use } \\
\text { raises concerns about privacy and human rights. } \\
\text { Sample questions: How are satellites used to track } \\
\text { animal species in remote areas? How can scientists } \\
\text { and environmentalists use this information to help } \\
\text { protect vulnerable species? What is the impact of the } \\
\text { use of speed limiters and tracking devices in the } \\
\text { trucking industry? What effect do lower truck speeds } \\
\text { have on highway safety and vehicle emissions? } \\
\text { (OME, 2008b, p.184) }\end{array}$ \\
\hline $\begin{array}{l}\text { Grade } 12 \text { Earth } \\
\text { and Space } \\
\text { Science: } \\
\text { Earth Materials }\end{array}$ & $\begin{array}{l}\text { Assess the direct and } \\
\text { indirect impact on local, } \\
\text { provincial/regional, or } \\
\text { national economies of the } \\
\text { exploration for and } \\
\text { extraction and } \\
\text { refinement/processing of } \\
\text { Earth materials (e.g., } \\
\text { gold, uranium, sand, } \\
\text { gravel, dimension stone, } \\
\text { fossil fuels). }\end{array}$ & $\begin{array}{l}\text { Sample issue: Diamonds are prized for industrial } \\
\text { and personal uses. The demand contributes to the } \\
\text { existence of illegal trade in "blood diamonds", in } \\
\text { which stones mined in war zones are sold and the } \\
\text { revenue is used to fund military action by insurgent } \\
\text { groups. The protracted wars devastate local and } \\
\text { national economies. } \\
\text { Sample questions: What are the effects on local } \\
\text { economies of oil extraction in Alberta, transportation } \\
\text { by pipeline through the Prairies, and refinement in } \\
\text { Ontario? How does the economic benefit of } \\
\text { manufacturing items using a mineral resource } \\
\text { compare to the economic benefits for the } \\
\text { communities that mine the resource? What is the } \\
\text { impact on the economy of local Aboriginal } \\
\text { communities of diamond mining on their lands? } \\
\text { (OME, 2008b, p. 144) }\end{array}$ \\
\hline
\end{tabular}




\section{Educator Agency}

Although science studies have traditionally housed education about environment, most specifically through environmental science, the partnership between secondary science education and STSE/EE has been criticized as theoretically and pragmatically incompatible (Gruenewald, 2004; Gruenewald \& Manteaw, 2007; Hart, 2002; Pedretti, 2003; Steele, 2011; Stevenson, 2007). Whereas elementary classrooms in Ontario generally support opportunities for integration and cross-disciplinary learning, secondary/high school programs persist in a model that keeps disciplines separate (Gough, 2002; Hodson \& Bencze, 1998). Further, traditional science pedagogy has been described as teacher-directed, content-based, and proud of an objective and value-free scientific process (Hodson, 2003). Consequently, the secondary science opportunities for pedagogies often associated with STSE/EE, described with phrases like learner-centered, interdisciplinary, systemic, issue-based, or place-based learning (Smyth, 2006) are difficult to enact. Moreover, there is a documented reluctance by secondary science educators to fully engage in critical studies of how society and environment are impacted by science and technology (Gayford, 2002; Tan \& Pedretti, 2010; Wals \& Alblas, 1997). Teaching and learning that delves into the realms of cultural and sociopolitical values often elicit between personal beliefs, sociocultural expectations, and peer culture within the science-teaching milieu (Kim, 2005; Pedretti, 2003).

Yet, arguably, the key to enacting any form of EE lies with the determination, knowledge, and agency of the educator tasked with its delivery, placing the onus of meaningful studies in EE directly on their shoulders. The personal conviction of the educator sustains and informs the environmental lessons that they teach (Hart, 2003; Karrow \& Fazio, 2010). Therefore, "it is important for each educator to attempt to clarify how he or she views the juncture between education and the environment and coherently translate that into practice" (Sauvé, 2009, p. 325).

Taking into account the peculiar and distinct EE/STSE landscape of rural northern Ontario, the study described assists in identifying how STSE is being taught in northern Ontario secondary science classrooms, and locates EE within the enactment of STSE education.

\section{Method for Research}

The research study had more than one distinct data collection phase and format, typifying a mixed methods approach (Creswell, 2009). Via an online survey Phase One provided general quantitative information that informed the subsequent qualitative interviews. Phase Two followed the work of two teachers as they collaborated to design and implement STSE lessons with a focus on EE. The study design progressed from multiple-participant survey responses that provided an overview of STSE/EE teaching, through a series of interviews that provided additional and specific concepts and perspectives, to an in-depth case study of two collaborating teachers.

\section{Phase One}

The voluntary online survey addressed the question: How do secondary science teachers in Northern Ontario understand and teach to the STSE expectations? The survey consisted of 34 single response items answerable on a graduated scale of: 1- strongly agree, 2-agree, 3-not sure,4- disagree, 5-strongly disagree. Survey questions covered teachers' understandings of 
STSE curriculum expectations and their focus on those expectations during course delivery. The survey url was sent to secondary science teachers in the northeastern Ontario public school board and the secondary school in Moosonee, Ontario. The response rate was approximately $45 \%$ $(n=26)$; this is an estimate based on the number of secondary schools in the catchment (10) and the estimated number of educators teaching science in each school.

Seven respondents agreed to be interviewed to further discuss their responses on STSE and EE in their classroom practice. The semi-structured interviews each lasted about 30 minutes and were conducted both face to face and through Skype; the anonymity of the interviewees has been preserved through the use of pseudonyms.

\section{Phase Two}

The second phase of the study asked the questions: What do the reported lessons in STSE actually look like? and How do teachers understand and implement EE through STSE? In this second phase of the study, research was focused on the collaboration between two secondary science teachers. Data collection took place over the course of a semester and is comprised of several semi-formal meetings and interview transcripts, and observations during classroom and field trip visits. It was anticipated that many of the teachers who had been interviewed in the first phase would agree to participate in the second phase of the study. In addition a number of teachers who had not been interviewed, but were aware of the study expressed interest in participating further, so the small number of participants who eventually remained with the study was surprising. Of the 12 who had expressed interest, two were assigned non-science courses, two were affected by maternity leaves and six cited insufficient time in their schedules. Thus, the focus of the study was narrowed to the work of two secondary science teachers as they chose to collaborate to deliver meaningful lessons in EE, through the STSE expectations.

Both teachers, Ned and Tess (pseudonyms), worked in the same secondary school in a town in northern Ontario and from the start of the project they were excited to collaborate. Tess was a teacher with five years of classroom experience who was teaching grade nine science courses and Ned had two years of classroom experience and was teaching grade nine science and grade 11 biology courses. Data collection took the form of interviews with Ned and Tess, and observations that I made as I visited the classes and accompanied them on their field trips. Tess and Ned's committed collaboration provided not only a gateway into understanding the work of northern educators, but from it there emerged an unexpected synergism. Both Ness and Ted offer compelling narratives as two northern Ontario born-and-raised educators, describing their trajectories towards becoming science teachers with a passion for EE.

\section{Analysis}

\section{Phase One}

Phase One survey data offered an overview of teacher perspectives on STSE in science curriculum, and indicated that STSE was being generally addressed in science lessons. The qualitative data was subjected to a grounded theory approach (Creswell, 2009) whereby, during numerous readings of the transcripts and notes, recurring ideas regarding teachers' comments on STSE were identified. The recurring ideas were then refined into themes such as the information gap and positioning STSE in a science unit, that are analyzed in detail below. 
Survey. Of the total number of secondary science teachers who responded to the survey, twothirds were male; two-thirds had teaching assignments that included courses other than science; the undergraduate science degrees held by the respondents were diverse, but most of the women held biology degrees; and one-third of the respondents had been teaching less than six years.

Based on the survey results (Table 2) it appears that respondents feel that: (a) the STSE expectations are important in their science teaching and (b) provide a context for student learning. Further, (c) respondents viewed science teaching as more than the transmission of content; (d) science teaching should include opportunities for decision-making, (e) for consideration of social and environmental issues, (f) for consideration of values, and (g) for taking action to solve problems. This is a general acknowledgement, on the part of the respondents, of the role importance of STSE in science education and a possible (though likely slow) shift in direction away from the traditional science pedagogy described earlier.

Table 2. Survey results showing trends as reported by secondary science teachers

\begin{tabular}{lcc}
\hline \multicolumn{1}{c}{ Survey Statements } & Mean $(M)$ & Variance \\
\hline $\begin{array}{l}\text { I am familiar with STSE expectations } \\
\begin{array}{l}\text { The STSE expectations are an important part of the science } \\
\text { curriculum that I teach. }\end{array}\end{array}$ & 2.0 & 0.7 \\
$\begin{array}{l}\text { STSE expectations provide a context for students to learn } \\
\text { science }\end{array}$ & 2.2 & 0.4 \\
$\begin{array}{l}\text { Content knowledge should be the primary focus of science } \\
\text { education }\end{array}$ & 3.4 & 0.8 \\
$\begin{array}{l}\text { Decision making skills should be an important part of a } \\
\text { science curriculum. }\end{array}$ & 2.0 & 0.2 \\
$\begin{array}{l}\text { Science teaching and learning should address social and } \\
\text { environmental issues }\end{array}$ & 1.6 & 0.3 \\
$\begin{array}{l}\text { Science and values education should not be coupled } \\
\text { STSE expectations require an interdisciplinary approach }\end{array}$ & 3.7 & 0.5 \\
$\begin{array}{l}\text { Promoting 'action' (personal, local) should not be the } \\
\text { business of public school science education }\end{array}$ & 3.4 & 0.8 \\
\hline
\end{tabular}

Note: Each survey statement was rated using a likert scale of 1 (Strongly Agree), 2 (Agree), 3 (Not Sure), 4 (Disagree), 5 (Strongly Disagree). 
More experienced teachers (5+ years of teaching experience) seemed to have a higher comfort level with non-traditional approaches to teaching science, with fully two-thirds of them indicating that development of skills, rather than acquisition of content knowledge, was more important. Those with less than five years of experience reported being less confident and more uncertain about undertaking lessons that were of a non-traditional nature.

The data is weakened by the small number of respondents overall; the total number of respondents represent only a fraction of the secondary science teachers working in northeastern Ontario, when all school boards are considered; and the voluntary nature of the survey and the interviews which may have been answered by a preponderance of respondents who already hold positive attitudes towards STSE and EE.

Interviews. Semi-structured interviews were conducted with seven of the survey respondents (Tess, Jeri, Sal, Radley, Ben, Hannah, and Fanny). All interviewees were teaching at least one secondary science course and all were from English public secondary schools in Northeastern Ontario, including two from Moosonee, situated on the James Bay.

Interview data was analyzed taking a constructivist grounded theory approach (Charmaz, 2006; Creswell, 2009). Charmaz (2006) described the process of constructing codes from qualitative data as a reflection of the views and values of the researcher; I recognize that despite my best efforts at objectivity, the data was processed through the lens of my personal experience. Upon numerous readings of the interview transcripts and notes, the recurring themes that I identified include the information gap, developing new lessons, positioning STSE in a science unit and in a program, and the importance for STSE/EE learning for northern students and assessment.

I have further organized the themes into three groupings: (a) the difficulties associated with preparing STSE lessons; (b) the importance of STSE and EE for their students; and, 3) living and teaching in northern Ontario.

\section{Difficulties associated with preparing STSE lessons the information gap}

Some science topics lend themselves easily to embedding EE, whereas others require extra preparation on the part of the teacher, particularly when providing for local contexts that might tap into students' prior knowledge and interests. Many of the interviewees expressed the concern that they were not experts, and often lacked background information pertaining to specific environmental issues. This requires of them extra time to research and prepare lessons; time that is at a premium for teachers who also coach school teams and work on committees. In addition, it takes time and effort to gather knowledge of, and make connections to, local resources, including suitable locales for out-of-classroom learning and experts in the community. Information technologies and media can be both friend and foe here. For example, although issues of mining waste are front and center in a number of northern communities, media and internet will often focus student and teacher attention on the concerns of other regions or countries. As one teacher put it: "It's a lot easier to talk about polar bears because we have all heard about those in the media!" (Hannah)

Developing new lessons. Another concern amongst interviewees was how to turn STSE expectations into lessons, particularly with a view to teaching about, in, and for the environment. 
A look back at the STSE expectations listed in Table 1 reveals that neither the expectations, the issues, nor the questions, indicate what the lessons should look like. This was disconcerting to several of the interviewees, who were unsure how to develop learning experiences for their students. As one interviewee pointed out, STSE can be uncomfortable for science teachers because they have been trained to "teach science consisting of facts and skills, not run debates in class or tackle issues and problems that have no answers." (Hannah). Other interviewees held similar views: "...you end up having to do this massive amount of background research for it, which I am not opposed to, but what do I do with it? How do I use that in the classroom to teach this unit?" (Radley), and “...you got an issue which is basically just a statement and what are you supposed to do with it?...its not exactly clear.” (Ben)

Positioning STSE within a unit. Neither is there an indication of how the STSE expectations should be positioned as part of the overall teaching and learning within the unit. Should an issues-based approach set the stage for learning content and skills, or should it be a culminating activity that builds on knowledge and skills already learned?

...he [a colleague] actually introduces the units with the [STSE] topics and the students struggle their way through...as they go through they are finding out they need to know this - so knowledge- and they need to know what this is - so knowledge again. So they are kind of working backwards, but I don't think backwards is the word for it, but starting with the big picture and then working backwards towards the concepts that you need to understand the big picture...he is getting to all the other aspects of the curriculum by using that. (Radley)

Positioning STSE within a science program. Hannah asked, "Do you teach the content and then work it into the environmental issues or do you talk about the issues first?" Her question speaks to the importance and re-positioning of the STSE expectations within the curriculum documents towards the beginning of the unit rather than at the end, as they had been in the previous edition. STSE expectations at the end of a unit sent the tacit message that they would be addressed in the classroom only if there was time. Placing the STSE expectations at the beginning of the unit (and the content knowledge expectations at the back) redefines their relative importance and encourages science educators to embrace them as part of their regular science curriculum. "I went to the ministry training and they said, 'That's why we put the all up front, because nobody ever really pays attention to them." (Ben) The clarity of the message is, however, blurred by years of traditional practice:

A lot of teachers told me that... when you look at the curriculum, if you are planning your course its annoying that they moved the STSE's to the front because now you have to go to find what you have to teach near the end...they just flip to the back anyways because they have to find out what the kids need to know for the test that they're going to give them...I think the mindset is still there, because when I started teaching I remember my program leader saying do that (STSE) if you have time. (Fanny)

Content is the third set. Does it always happen that way? No. I personally am still trying to make that flip. (Hannah)

Assessment of STSE student learning. Finally, all interviewees expressed concern over the assessment of STSE and EE expectations, stemming in part from its problematic nature already 
discussed, whereby the language of the expectations gives little pedagogical guidance. Assessment of STSE expectations requires strategies other than traditional science assessments that indicate the retention of content knowledge and the acquisition of investigative lab techniques; there are no definitive correct answers to the issues and questions presented by the STSE expectations.

The opportunity to "test for correctable answers" must be supplanted by assessment strategies, such as rubrics, that allow teachers to assess student engagement and application of their knowledge and skills. After collaborating on a rubric, first with her students, and then with a colleague, one interviewee explained:

...this particular rubric I think I could use for quite a few STSE assignments because I've written it in a way that I feel is not specific for a certain product or topic. Rubric experts might say that is flawed or there is something wrong with that. But I think the students know what is expected, ... it is general enough that it allows me to differentiate my instruction or my assessments. (Tess)

A number of the interviewees expressed their discomfort with rubrics as being too subjective and open to interpretation, which is a predictable response from educators who have been trained in the acquisition of content knowledge and skills. "I can't say I'm a huge fan (of rubrics)...there is a lot of wiggle room. They enable you to focus more on the the experience and the doing...a test is right or wrong, there is no grey..." (Hannah)

I'm mainly a checklist type of guy. At the start of the year, for the science labs and everything, I say "okay, we're going to do formal lab reports and here's the things for assessment." And I go through with them and I say, "okay, here's what you need" and I list all the things, and "here's how you do this, and there's what I'm looking for" and they have this checklist so when they go through with their partner and write up their labs they can exchange and say "do we have this, yes, yes, yes". (Ben)

What students need. Overwhelmingly, interviewees spoke to the importance of the contexts that STSE provides for student engagement and the development of critical thinking and problem solving skills.

...they [the students] don't necessarily need to know the information because they have access to it. They need to know how to use the information, they need to know how to solve problems, they need to know how to work with people. (Hannah)

Ben spoke of his concern for students who were learning to transfer their knowledge to real-life situations; Hannah talked about the need for some of her students to realize that their choices have impacts and that there is a "reality beyond themselves"; Fanny discussed how most of her students would never be scientists, but they should have the skills to be critical of information from media; Sal and Hannah both expressed their intentions to provide local handson experiences that students could relate to; Radley found that STSE expectations make the curriculum practical and tangible for students, particularly those who are bored and question the usefulness of the information that is presented to them; Jeri felt it was important that students see various perspectives of scientific issues; and finally, Tess describes how she tapped into student engagement through an STSE assignment:

...in my college level physics I have a lot of boys, they come to school on snowmobiles, that's how they come to school every day. So in the motion unit they wanted to do something related to snowmobiles or vehicles...(Tess) 
Teaching in northern Ontario. Many of the interviewees confirmed that they enjoyed living and teaching in the northern part of the province, since they were able to take advantage both personally and professionally of having a "wilderness at your doorstep to play in" (Sal). Opportunities for out-of-classroom learning in natural environments are often more accessible and many of the interviewees took advantage of this:

I can simply walk out the end of the school just in the backyard with my kids and we've got wilderness right there. We've got bush [forest], we've got a little stream ecosystem...so we can go there to collect organisms. (Sal)

But teaching with a wilderness in the backyard comes with a downside. Although the internet and other media is useful for gathering information about the world beyond the forests, students living in isolated northern communities do not necessarily develop a strong sensibility or understanding of issues beyond their communities. Admittedly, a local focus, such as placebased learning (Gruenewald, 2009) for STSE and EE is important, but a broader understanding of societal and environmental issues is equally important, particularly for secondary students as they begin to define themselves as global citizens. Indeed a number of the interviewees commented on the lack of environmental knowledge and sensibility of their students who had grown up in northern locales:

To be honest, I was kind of hoping that my students would be a little more familiar with the local environment [Hudson Bay Lowlands]. For instance I did a review question to just name five trees... and [they said] 'palm tree' or 'Christmas tree'... Most of the species would be ones from the media than ones actually native to where they live. (Jeri)

Hannah worried that her students did not really appreciate their surroundings and so were oblivious to crises in environment:

...they are not exposed to the shortages and the inconveniences. Down south they are hyper aware of recycling programs and impacts...we have the resource-based industries [mining and logging] that we can relate to...but as far as making good environmental choices it doesn't seem to touch us up here...there just doesn't seem to be that awareness and that drive.

Hannah also speaks to the general mindset of her colleagues in this regard:

They have heard [the three R's] a bazillion times but how many times a day do I pick through the garbage...they know...its just easier. It's not just students, its a pervasive mindset. It's a lack of awareness, its a culture...we are a very wasteful, resource-abusing people...we are quite oblivious of the reality of the crisis.

The comments of the interviewees confirm the importance of EE embedded in STSE expectations as one of the critical elements in the education of northern youth, and perhaps also peers.

\section{Phase Two - Collaborating Science Educators}

By the end of Phase One data collection I was becoming increasing intrigued by what STSE lessons might look like, particularly if $\mathrm{EE}$ was an embedded element. Certainly secondary science teachers in Northeastern Ontario were reporting that such lessons were being taught, and it became incumbent to observe a number of these. Consequently the study was narrowed to follow the work of two secondary science teachers who chose to collaborate to explicitly embed EE in their science lessons. 
The lessons were situated in the grade nine unit titled Biology: Sustainable Ecosystems. The teachers, Tess and Ned, decided to focus student learning on soils and food production, with particular emphasis on organic foods. This was a deliberate and important choice since their students live in an area of Ontario that has a short growing season and produces very little of the food sold in local grocery stores. Most students are not able to speak knowledgeably about food production. The students participated in three activities: they planted bean and corn seeds in class and documented plant growth over time; a local organic farmer was invited to their classes to speak about maintaining healthy soils through organic farming practices, and also about benefits of organically produced foods; and the students toured the local organic farm where they observed a variety of soils, watched fieldworkers transplant seedlings, and interacted with a variety of farm animals being raised through organic and humane methods. As a participant in the field trip I was able to observe and speak with students. Although they listened attentively to the explanation of organic crop production, a number of them shared that studying or working with plants held little appeal for them. However, their interest in the heritage chickens, the African goats, and the endangered species of turkeys was genuine and prompted many questions and comments.

As I met and worked with Tess and Ned it became apparent that through their lessons about food they had a genuine desire to provide a rich, transformatory experiences for their students. That is, they wanted the lessons to have personal meaning for the students, beyond content acquisition; they hoped to shift the students' attitudes and behaviours towards living in more environmentally sustainable ways.

Like anything, change takes time and I think especially now that the environment is at the forefront we can take time to do it and kids will get exposed to it at school and they'll bring it home and hopefully it'll become a part of their adult life. (Ned)

I asked Tess and Ned how their attitudes towards environment and EE had developed, realizing from earlier interviews in Phase One that many teachers as well as students in the north are not committed to environmental concerns to the point of overtly incorporating elements of EE in their practice. Although they were both 'born and raised in the north', their two answers were quite different.

Ted described camping trips with his parents as a child; learning in nature, about nature and the responsibility to protect nature, at an early age. He attributed his attitudes also to his studies in science and biology and eventually as a young man to his peer group, from whom he learned to attend more closely to his food choices. Being a teacher was a second career for Ned, as he had already trained for and worked in the health care field. Thus, while he was a relatively new teacher, he was not a young teacher, and had already developed a strong sense of purpose and confidence.

Tess did not recall childhood experiences in nature similar to those of Ned. Her interest developed when, as a very new teacher, she became part of an action research project that addressed EE curriculum issues in science. Her further influences came from two other teachers who served as mentors over the years and encouraged her involvement in school and professional development activities focusing on EE. Her work with the student council also provided her with opportunities to tackle environmental concerns at her school.

A study conducted in Australia, Canada, and the UK, (Palmer, Suggate, Robottom, \& Hart, 1999) identified influential people (family, other adults and teachers), childhood experiences of nature and work as the most significant factors that led educators toward EE. Remarkably, these 
are exactly the main reasons given by Tess and Ned for their enthusiasm for EE. And these three factors should be taken as further reasons for providing opportunities for students (and teachers) to learn outside the classroom.

[the] results presented...suggest the importance of providing young people - indeed people of all ages - with opportunities for positive experiences of nature and the countryside. It is those 'in' and 'with' the environment experiences that appear to be fundamental to the development of long-term environmental awareness and concern. (Palmer et. al., 1999, p. 199)

Given that Phase One survey data suggested that teachers with more years of experience are more inclined to contemplate and/or embark on a shift in their practice, the enthusiastic collaboration between Ned and Tess is somewhat unique. However, they had both independently developed a strong environmental ethic and perhaps the opportunity to collaborate in a research project acted as a form of permission for Tess and Ned to break away from traditional or normative practices much earlier in their careers than might have been expected.

\section{Discussion and Implications}

The boreal region of northern Ontario is a special place and worthy of consideration from an education perspective, since it is through education, I believe, that we can address social and environmental well-being and sustainability. My research and teaching find focus at the intersection of secondary science, STSE, and EE, especially as they are enacted in formal schooling and particularly in this case as they are enacted in northern Ontario. While encouraging progress has been made embedding STSE and EE in formal science curriculum documents in Ontario, the real issue is one of practice. The Ontario science curriculum tasks environmental education with learning about, in, and for the environment; learning that would include not only nature studies (about and in the environment) but also studies that connect environment to social and justice issues, and that advocate for positive action and activism. Recognizing that it is not the curriculum but the personal beliefs of the individual educator that determine how and what is taught, I was led to wonder whether secondary science educators were presenting STSE and EE learning opportunities that provided students with opportunities to think critically about environmental and social issues related to science, and to take action where appropriate. This is a pertinent query at the secondary level, where science studies have tended to follow a traditional route of science content and skill acquisition, with a leaning towards valuefree inquiry, and disciplinary isolation.

The questions informing this study were: How do secondary science teachers in northern Ontario understand and teach to the STSE expectations? What do the reported lessons in STSE actually look like? and How do teachers understand and implement EE through STSE? The study was conducted in two phases: surveys and interviews, and a case study of two collaborating teachers. Arising from the data analysis of both research phases, and coupled with current understanding of STSE and EE teaching and learning in formal education settings in Ontario, I present below six Implications for consideration. Based on Charmaz's (2006) description of grounded theory as a means for data analysis, the implications that I propose should not be taken as absolute and conclusive, instead they should be seen as a basis for discussion and further investigation.

\section{Implication \#1: Secondary Science Teachers are Shifting their Practice towards STSE/EE}


Generally, secondary science teachers in northern Ontario are reporting that STSE expectations are gaining importance insofar as they agree that social and environmental issues, along with ethics and values, have a place in science curricula. Further, they recognize the importance of problem solving and decision-making in science studies inasmuch as these support the development of students' citizenship. This overall stance is in keeping with the intentions of STSE to "place science squarely within social, technological, cultural, ethical, and political contexts" (Pedretti \& Nazir, 2011, p. 602). Moreover, this result hints at a change in attitude from that reported (e.g. Gayford, 2002) in which science teachers are reluctant to move away from traditional science pedagogies. A decade ago, Gough (2002) pointed out the dwindling student interest in secondary science studies and made a strong case for providing context to boost student engagement. Ten years later, teachers are reporting their belief in the importance of providing opportunities for decision-making, and for examining the social and environmental issues impacted by science and technology in their science programs. Teachers increasingly recognize the shortcomings of a science curriculum that does not acknowledge the impact that science and technology have on people and their environments, both locally and globally. Their responses to the survey and interview questions indicate a change, a shift in beliefs held about the nature of teaching science, and a concurrent shift in practice.

Nonetheless, the survey results are purely self-reported and may represent either the actual state of practice and/or the state of practice that the respondents believe is preferable.

\section{Implication \#2: STSE Continues to be Problematic for Science Teachers}

While the shift of science teachers towards deliberate inclusion of STSE and EE is encouraging, there is considerable evidence that such a shift is fraught with difficulties. Indeed, discussions regarding the challenges of implementing STSE are not new, yet it remains important to consider the evolving practicalities of enacting a form of curriculum that is problematic. An unanswered dilemma for teachers is the positioning of STSE within a science program and within a unit. The re-placement of the STSE expectations to the front and center of each science unit challenges the traditionally accepted view that science learning is a primarily content and lab-skill driven discipline. Furthermore, there is confusion whether the STSE issues should define the content and skills that need to be learned or whether the STSE issues should be presented only after the content and skills have been attained. Are issues related to science and technology the very reason why we should be teaching and learning science? Or are those issues an add-on to the curriculum content if there is time? This remains a conundrum for many science teachers.

The information gap requires that teachers become knowledgeable and remain current on topics that are far-ranging throughout the sciences; then teachers must develop new lessons on those topics, such that students will be challenged to think critically, to problem solve, and to engage in inquiry. Teachers are taking increasingly non-traditional approaches to teaching secondary science curriculum in Ontario, despite the difficulties such a shift might entail. The STSE expectations for teaching science require additional teacher content and pedagogical knowledge; teachers who have considered themselves experts in their fields find themselves having to research and prepare material that is new for them, and in many cases to hand over that research to their students. This speaks to issues of confidence, and the shift of the role of the teacher from gatekeeper of knowledge to facilitator of knowledge acquisition and interpretation. It also speaks to many additional hours of lesson preparation time for teachers who already have 
full schedules.

One of the most difficult practicalities that STSE presents to teachers is in student assessment and evaluation. Shifting from long-established assessments for specific content and skill acquisition using straightforward testing methods, to identifying student skill development critical thinking, logical reasoning, or creativity, is quite another matter that, for many secondary science teachers, presents a departure from their customary practice. Both teaching STSE and assessing student learning become more complex than the administration of a series of wellestablished lessons and then a test of acquired content knowledge.

\section{Implication \#3: Teaching in Rural Northern Ontario Presents Unique Conditions and Challenges}

Teaching in the north is an additional dimension within the already complex task of teaching STSE. Northern sensibilities around environmental sustainability are reportedly not as pervasive as those in the southern part of the province, neither amongst students nor teachers. And perhaps because wilderness is at the doorstep, a sense of environmental crisis is not prevalent, nor is the overarching belief of the need for personal acts of stewardship and sustainability. The teachers confirmed that northern Ontario is a setting different from its southern urban counterpart, and that its people, students, and teachers need to pay more attention to environmental issues.

Moreover, the isolated nature of some of the students/schools creates a disconnect relating to environmental, social, and cultural perspectives between north and south, between rural and urban, between resource-extraction and industrially based communities. A strong EE emphasis in secondary science STSE should be seen as imperative for students and educators alike, which would require focused professional and personal development opportunities.

\section{Implication \#4: Science Teachers in Northern Ontario Recognize their Need for PD}

As stated above, the challenges of teaching EE within STSE, particularly in the north, speak to the immediate and ongoing need for professional development opportunities that focus specifically on the challenges that secondary science teachers have identified. The value of ongoing collaboration is confirmed (see also Wallace \& Louden, 1994), as are multiple opportunities for sharing practice with like-minded educators. Carefully designed and well supported professional development experiences have far-reaching and amplifying effects for the teachers involved.

It seems that teachers with more years of experience are more inclined to contemplate and/or embark on a shift in their practice. This makes the enthusiastic collaboration between Ned and Tess somewhat unique, as they are both less-experienced educators, however, they had developed a strong environmental ethic. An opportunity to collaborate in a research project can be viewed as a form of permission to break away from traditional or normal practice. Certainly Ned and Tess took advantage of that opportunity. Professional development, whether in the form of workshops, seminars, or longer-term action research projects and collaborations are key to improved education. And equally important is the opportunity for educators to identify their professional development needs for the purpose of designing and/or subscribing to appropriate activities. 


\section{Implication \#5: The STSE Framework Provides a Useful Lens for Data Analysis}

A component of relevant professional development should include an examination of the Pedretti and Nazir (2011) STSE framework as a means of analysis of science curriculum and lessons. Recall that the STSE framework consists of six currents: Application/Design, Historical, Logical Reasoning, Value Centered, Sociocultural and Socio-Ecojustice.

The classroom lessons that were observed during the study were deconstructed through the lenses of the six currents as a way to examine the utility of the framework for the purpose of providing pedagogical clarity to educators. For example, the lessons that required students to consider evidence for the personal, social, and environmental health benefits of growing and consuming organic foods fell within the Logical Reasoning current. Students were challenged to think critically about the sources of the foods that they consumed and the benefits associated with them. Further, as students found themselves thinking about the choices they make around eating meat from animals that are inhumanely raised and slaughtered, they were working within the Value Centered current. Many of them realized that the welfare of animals raised for food had ethical ramifications for them. The Sociocultural current was powerfully represented by the voice of the organic gardener who, during another lesson, introduced an alternative knowledge system (organic food production). Students were challenged to recognize a broader cultural context for learning the science of soils, and to consider that localities other than those sustained by mining and forestry have equally valid and useful knowledge systems.

While strong links were not found for the other three currents, this does not negate their usefulness for purposes of analysis. It is hardly likely that three lessons will fully encompass all six currents. However, using the STSE framework as a foundation for analyzing multiple lessons within a unit, or an entire course, will provide educators with a unique perspective of their practice. The STSE framework is richly detailed with descriptions, pedagogical approaches and teaching strategies that can inform and support a shift in practice towards a contemporary science teaching practice. Indeed, an analysis exercise using the framework would likely prove elucidating for both individual and collaborating educators.

However, as useful as the STSE framework is in its current form, the data analysis does suggest that there is an important set of activities and experiences missing.

\section{Implication \#6: An EE Current is Needed in the STSE Framework}

Earlier, the theoretical link was made between EE and STSE, so it is interesting to note that there is not a strong focus on EE in the six STSE currents of Pedretti and Nazir (2011). Certainly elements of EE can be found in the background, for example: in the Application/Design current there is potential for examination of environmental impacts of new or modified technologies; within the Logical Reasoning current can be nested the environmental sciences; the Value Centered current entertains possibilities for studying various philosophies such as deep ecology, ecofeminism or an ethic of care; the Sociocultural current has strong links to place-based EE and indigenous environmental paradigms; and, the Socio-Justice current is an obvious place for the examination of environmental justice issues. Yet, considering my conversations with the teachers and my observations of the students particularly during the field trip to the organic farm, a stronger voice for EE is missing from the framework.

The teachers talked about wanting their students to feel comfortable in natural environments, and to learn to care deeply about them. I watched the students connect to the 
natural environment sensuously, that is, they enjoyed the sun and wind on their faces, theyand they keenly observed and interacted with the animals. I was reminded that EE must be about more than thinking logically/critically about environmental issues, more than taking action in the interests of eco-justice. Environmental education must be felt as much as reasoned. To that end I suggest that Nazir and Pedretti (2011) have provided too weak a focus on environment/nature in their STSE currents. There is a solid literature base underscoring the importance of a sensuous/affective/intuitive connection to nature (for a comprehensive bibliography see Council of Outdoor Educators of Ontario, 2007), and an equally strong foundation in the literature connecting EE to science and to STSE (e.g. Gough, 2002; Hart, 2002, 2007; Hodson, 2003, 2010; Smith 2007; Tan \& Pedretti, 2010). Moreover, the work of the teachers in this study demonstrates their intention to provide transformatory EE experiences for their students through the STSE expectations.

Rather than have EE hover in the background of the six STSE currents proposed by Pedtretti and Nazir (2011), I would suggest that it be added as a seventh current. Its Focus would be to understand that humans exist within/as part of, and not separate from, the natural environment, and further that human actions have significant impact on environment. The Educational Aims of an EE current would be Environmental Citizenship, and Transformation/Agency, and its Dominant Approaches would include Affective, Intuitive, Sensory, Experiential, Place-based, Creative, and Immersive. Examples of Strategies used in an EE current would include integrated activities taking place out-of-classroom, out-of-doors, within natural environments.

I sensed a genuine commitment on the part of Ted and Ness, to teach science in a way that goes far beyond the transmission of content. They wanted their students to understand their role within society as consumers and within the environment as caretakers. And they wanted their students to spend time out-of-classroom, out-of-doors. Ted and Ness's commitments to EE are a result of their trajectories towards embracing EE in their teaching practice and their personal lives. At first glance their stories seem quite different - Ted recalled childhood experiences while Ness attributed her commitment to EE to influential people in her adult life and work. But according to Palmer et al. (1999) childhood experiences, influential people and work are three of the most significant factors leading to interest and commitment to EE. Ted and Ness' stories should have resonance for the STSE framework, and for secondary science teaching practice. For the STSE framework to be complete and for EE to fully embedded in science teaching and learning, both students and teachers need to spend time in nature and interact with environment. They need to meet and interact with others who have a passion for environmental issues, and they need to be prepared to find mentors and/or act as mentors for others. They need to gain knowledge about environmental issues, and confidence in their ability to make good decisions and act on them. Initiatives such as environmental clubs, activism for social and environmental issues and further personal and professional development in EE should be encouraged and supported. That falls well within the purview of the Ontario Ministry of Education definition of EE, which is to teach in, about, and for the environment. And it should certainly be considered as an important seventh addition to the six currents of the STSE framework. 


\section{Recommendations}

The six implications discussed at length in the preceding paragraphs inform the following recommendations:

First, given evidence that secondary science teachers are making a shift in practice to include issues-based STSE science teaching and learning, new research directions should be taken. For example: Is the shift in science teaching perspective peculiar to northern Ontario, or is the shift occurring in other parts of Ontario? in other provinces? Moreover, the disparity between perspectives and practice should be further explored, leading to questions such as: Which factors impact the degree to which science teachers' EE perspectives or beliefs are reflected in their practice? The personal and professional EE trajectories of teachers appear to play a significant role in determining how they will address STSE/EE lessons inside (and outside) of their classrooms. The EE trajectories of science teachers should be further explored as a means to inform directions for professional development and professional support.

Important also is the question of how much STSE teaching and learning is enough in a science program. How much time should be given over to STSE in order to meet curriculum obligations? to hold student interest? and to adequately connect pure science learning to local and global contexts? Examination and discussion of those issues will help teachers who struggle with the thorny problem of how to position STSE in their teaching.

In addition, research focusing on rural northern science education is highly recommended, as there is a distinct gap in the academic literature, as well as a pragmatic lack of understanding, of what is entailed in teaching science in the boreal north.

Second, a current for EE should be created within the STSE Framework. It is important that curriculum be designed and implemented within theoretical frameworks that inform and unify it. While the STSE framework has six currents that provide meaningful and complex understanding of the STSE intentions and expectations in secondary science, I believe that the 'E' in STSE would be strengthened by the addition of an EE current. An EE current in the STSE framework would fill a gap that has been identified both through the literature and through an analysis of teaching practice in this study, by bringing attention to the intuitive, affective, sensory, experiential, and creative elements of EE within science curriculum.

Third, create a curriculum analysis tool based on the STSE Framework. Once the STSE framework is enriched by a seventh current, the framework has the potential to inform and augment the STSE practice of science teachers. However, currently the framework resides in a scholarly paper, a version so detailed and comprehensive that it is too wieldy for use by practicing teachers. A functional curriculum analysis tool is needed, based on the STSE framework, concise in its terminology and easy to administer. Such a tool would provide teachers with a detailed review of their STSE teaching, including suggestions to improve and supplement their lessons.

Fourth, assist secondary science teachers to access meaningful professional development. Professional development efforts should focus particularly on the areas of STSE that the teachers have identified as needing clarification. In addition, there is a need for professional development to address issues related to the shift in the role of the science teacher from traditional knowledge keeper and transmitter to facilitator/interpreter/mentor of science studies. For the teachers in the study, their changing role was the basis of many of their concerns and difficulties with implementing STSE and EE. While workshops and seminars can be useful, teachers need time and multiple opportunities to enact changes in their practice. Thus, it is highly recommended that 
professional development occur over a longer term. Long-term projects and collaborations, such as the one described in this study seem to be worthwhile for developing and honing teacher practice and should be particularly encouraged and supported.

Finally, inform and inspire pre-service science teachers. It is during their extended study time that pre-service teachers have the opportunity to engage in science curriculum as a unified enterprise that continues to shift its focus. Pre-service teachers will benefit from being introduced to the STSE and EE expectations embedded in science curriculum as a way to develop nontraditional attitudes towards understanding and teaching science. The STSE/EE combination encourages examination and development of pedagogies unfamiliar to traditional science education. Pre-service teachers will not need to engage in the hard work of shifting their practice, if they enter their science teaching careers already prepared to addresses STSE/EE in their classrooms.

This study, based in the northern boreal region of Ontario, Canada has potential to inform efforts at STSE/EE teaching in other rural, isolate regions, as well as in densely populated, urban areas. The shift in focus amongst many science educators towards inclusion of significant, contextual STSE/EE lessons is heartening, as is their willingness to examine and improve their practices. I applaud the commitment of individual teachers who continue to be a driving force in the shift towards developing authentic and relevant EE/STSE lessons for their students. I believe their work will contribute to a robust EE/STSE component in science teaching and learning that will, in turn, expand and strengthen the understandings that northerners have of their extraordinary boreal surroundings. Through patient and passionate education the boreal region will remain treasured by its human inhabitants. 


\section{References}

Canadian Boreal Initiative. (n.d.) About Canada's Boreal. Retrieved April 2, 2013, from http://www.borealcanada.ca/boreal-did-you-know-e.php

Charmaz, K. (2006). Constructing grounded theory. London, UK: Sage.

Council of Ministers of Education, Canada, CMEC. (1997). Common Framework of Science Learning Outcomes: Pan-Canadian Protocol for Collaboration on School Curriculum Toronto: Council of Ministers of Education, Canada.

Council of Outdoor Educators of Ontario. (2007). Reconnecting children through outdoor education: A research summary. Toronto, Canada: COEO.

Creswell, J. (2009). Research design: Qualitative, quantitative and mixed methods approaches. Thousand Oaks, CA; SAGE publications.

Fazio, X., \& Karrow, D. D. (2011, April). Exploring school-based environmental education practices. Paper presented at the meeting of the National Association for Research in Science Teaching, Orlando, Florida.

Fowler, S., Zeidler, D., \& Sadler, T. (2009). Moral sensitivity in the context of socioscientific issues in high school science students. International Journal of Science Education, 31(2), 279-296. doi:10.1080/09500690701787909

Gayford, C. (2002). Controversial environmental issues: A case study for the professional development of science teachers. International Journal of Science Education, 24(11), 1191-1200. doi:10.1080/0950069021013486

Gough, A. (2002). Mutualism: A different agenda for environmental and science education. International Journal of Science Education, 24(11), 1201-1215. doi:10.1080/09500690210136611

Greenwood, D. (2009). Place: The nexus of geography and culture. In M. McKenzie, P. Hart, H. Bai, \& B. Jickling (Eds.), Field of green: Restorying culture, environment and education. Cresskill, NJ: Hampton Press.

Gruenewald, D. (2004). A Foucauldian Analysis of Environmental Education: Toward the Socioecological Challenge of the Earth Charter. The Ontario Institute for Studies in Education of the University of Toronto Curriculum Inquiry 34(1), 71-107.

Gruenewald, D., \& Manteaw, B. (2007). Oil and water still: How No Child Left Behind limits and distorts environmental education in US schools. Environmental Education Research, 13(2), 171-188. doi:10.1080/13504620701284944 
Halfacree, K. H. (1993). Locality and social representation: Space, discourse and alternative definitions of the rural. Journal of Rural Studies, 9(1), 23-37.

Hart, P. (2007). Environmental education. In S.K. Abell \& N.G. Lederman (Eds.), Handbook of research in science education (pp. 689-728). New Jersey: Lawrence Erlbaum Publishers.

Hart, P. (2003). Teachers' thinking in environmental education: Consciousness and responsibility. New York: Peter Lang.

Hart, P. (2002). Environment in the science curriculum: The politics of change in the PanCanadian science curriculum development process. International Journal of Science Education, 24(11), 1239-1254. doi:10.1080/09500690210137728

Hodson, D. (2010). Science education as a call to action. Canadian Journal of Science, Mathematics and Technology Education, 10(3), 197-206.

Hodson, D. (2003). Time for action: Science education for an alternative future. International Journal of Science Education, 25(6), 645-670. doi:10.1080/14926156.2010.504478

Hodson, D., \& Bencze, L. (1998). Becoming critical about practical work: Changing views and changing practice through action research. International Journal of Science Education, 20(6), 683-694.

Karrow, D. D., Fazio, X., \& Dusto, C. (2012, October). Exploring environmental education from a rural education perspective. Paper presented at the meeting of the North American Association of Environmental Education, Oakland, California.

Karrow, D. D., \& Fazio, X. (2010). NatureWatch, schools and environmental education practice. Canadian Journal of Science, Mathematics and Technology Education, 10(2), 160-172. doi:10.1080/14926156.2010.504478

Kim, M. (2005). Ethics of pedagogy in world-becoming: Contemplations on scientific literacy for citizenship. Delta Kappa Gamma Bulletin, 71(3), 52-58.

Lee, H., Chang, H., Choi, K., Kim, S., \& Zeidler, D. (2012). Developing character and values for global citizens: Analysis of pre-service science teachers' moral reasoning on socioscientific issues. International Journal of Science Education, 34(6), 925-953. doi:10.1080/14926156.2010.504478

Louv, R. (2005). Last child in the woods: Saving our children from nature-deficit disorder. Chapel Hill, NC: Algonquin Books.

Ontario Curriculum Council. (2007). Shaping our schools, shaping our future: Environmental education in Ontario schools. Toronto, Ontario: Queen's Printer for Ontario. 
Ontario Ministry of Education, (2009). Acting today, shaping tomorrow: A policy framework for environmental education in Ontario schools. Toronto, Ontario: Queen's Printer for Ontario.

Ontario Ministry of Education. (2008a). Science: Grade 9 and 10, revised. Toronto, Ontario: Queen's Printer for Ontario.

Ontario Ministry of Education. (2008b). Science: Grade 11 and 12, revised. Toronto, Ontario: Queen's Printer for Ontario.

Palmer, J., Suggate, J., Robottom, I., \& Hart, P. (1999). Significant life experiences and formative influences on the development of adults' environmental awareness in the UK, Australia and Canada. Environmental Education Research, 5(2), 181-200. doi:10.1080/1350462990050205

Pedretti, E. (2003). Teaching science, technology, society and environment (STSE) education: Preservice teachers' philosophical and pedagogical landscapes. In D. L. Zeidler (Ed.), The role of moral reasoning on socioscientific issues and discourse in science education. Dordrecht, Netherlands: Kluwer Academic Press.

Pedretti, E., \& Little, C. (2008). From engagement to empowerment: Reflections on science education for Ontario. Toronto, Canada: Pearson.

Pedretti, E., \& Nazir, J. (2011). Currents in STSE education: Mapping a complex field, 40 years on. Science Education, 95(4), 601-626. doi:10.1002/sce.20435

Sauvé, L. (2009). Being here together. In M. McKenzie, P. Hart, H. Bai, \& B. Jickling (Eds.), Field of green: Restorying culture, environment and education. Cresskill, NJ: Hampton Press.

Sauvé, L. (2005). Currents in environmental education: Mapping a complex and evolving pedagogical field. Canadian Journal of Environmental Education, 10, 11-37.

Smith, G. A. (2007). Place-based education: Breaking through the constraining regularities of public school. Environmental Education Research, 13(2), 189-207. doi:10.1080/13504620701285180

Smyth, J. C. (2006). Environment and education: A view of a changing scene. Environmental Education Research, 12(3), 247-264. doi:10.1080/1350462950010101

Statistics Canada. (n.d.) Rural and Small Town Canada Analysis Bulletin, 7(7). retrieved April 12, 2013 from http://www.statcan.gc.ca/pub/21-006-x/2007007/6000446-eng.htm 
Steele, A. (2011). Beyond contradiction: Exploring the work of secondary science teachers as they embed environmental education in curricula. International Journal of Environmental and Science Education, 6(1), 1-22.

Stevenson, R. (2007). Schooling and environmental education: Contradictions in purpose and practice. Environmental Education Research, 13(2), 139-153. doi:10.1080/13504620701295726

Tan, M., \& Pedretti, E. (2010). Negotiating the complexities of environmental education: A study of Ontario teachers. Canadian Journal of Science, Mathematics and Technology Education, 10(1), 61-78. doi:10.1080/14926150903574320

Wallace, J., \& Louden, W. (1994). Collaboration and the growth of teacher knowledge. Qualitative Studies in Education, 7(4), 323-334. doi:10.1080/0951839940070403

Wals, A., \& Alblas, A. (1997). School-based research and development of environmental education: A case study. Environmental Education Research, 3(3), 253-26. doi:10.1080/1350462970030301

Zeidler, D., Sadler, T., Simmons, M., \& Howes, E. (2004). Beyond STS: A Research-Based framework for socioscientific issues education. Science Education, 89(3), 357-377. doi:10.1002/sce.20048 